\title{
Effect of Seed Source on Physical Properties of Scots Pine (a Case Study in Neka, (ran)
}

\section{Utjecaj podrijetla sjemena na fizikalna svojstva drva običnog bora (studija slučaja u Neki, Iran)}

Original scientific paper - Izvorni znanstveni rad

Received-prispjelo: 10. 8. 2012.

Accepted-prihvaćeno: 21. 6. 2013.

UDK: $630 * 232.3 ; 630 * 812.23 ; 630 * 812.42 ; 674.032 .475 .442$

doi:10.5552/drind.2013.1239

\begin{abstract}
This study investigated the seed source effect on the physical properties of exotic Scots pine (Pinus sylvestris). For this purpose, nine clear pine trees grown from the Spanish, Armenian and Serbian (part of former Yugoslavia) seed sources were selected from the Vanamak-Neka (eastern part of Mazandaran province) and a disc was cut from each tree at breast height. Testing samples were prepared based on the ISO standard to estimate the oven-dry density, basic density, volumetric shrinkage and volumetric swelling. Then, the results were studied by using the variance analysis test (ANOVA) and Duncan's table. The results indicated that the effect of seed sources on the above mentioned properties were significant. All of the physical properties of Scots pine grown from the Spanish seed source were higher. There were no significant differences between the Armenian and Serbian seeds in the density and dimensional changes of the wood (volumetric swelling and volumetric shrinkage). The relationships between different wood properties were analyzed by applying the linear regression. There was a weak and negative relationship between oven-dry and basic density and longitudinal and diametrical growth of the trees. The correlation between oven-dry density and dimensional changes of the wood showed that there was a positive relationship between the mentioned properties in all the three seeds, while the correlation coefficient of the Armenian seed was stronger than that of the other two seeds.
\end{abstract}

Keywords: seed sources, Scots pine, oven-dry density, basic density, volumetric shrinkage, volumetric swelling

SAŽETAK • U radu se prikazuje istraživanje utjecaja podrijetla sjemena na fizikalna svojstva egzotičnog drva običnog bora (Pinus sylvestris). Za tu svrhu sa staništa Vanamak-Neka (istočni dio pokrajine Mazandaran) izdvojeno je devet čistih stabala običnog bora čije je sjeme podrijetlom iz Španjolske, Armenije i Srbije (bivša Jugoslavija) te je ispiljen disk na prsnoj visini svakog stabla. Ispitni uzorci pripremljeni su na temelju ISO standarda za određivanje gustoće apsolutno suhog drva, standardne gustoće, volumnog utezanja i volumnog bubrenja. Zatim su rezultati analizirani uz pomoć testa analize varijance (ANOVA) i Duncanove tablice. Rezultati su pokazali da je

\footnotetext{
${ }^{1}$ Authors are Assistant Professor and MSc graduated at Department of Wood and Paper Science and Technology, Sari Branch, Islamic Azad University, Sari, Mazandaran, Iran. ${ }^{2}$ Author is professor at Department of Wood and Paper Science and Technology, Chaloos Branch, Islamic Azad University, Chaloos, Mazandaran, Iran. ${ }^{3}$ Author is professor at Agriculture \& Natural Resources Research Center of Mazandaran, Sari, Iran.

${ }^{1}$ Autori su profesor i asistent Odjela za znanost i tehnologiju drva i papira, Islamsko sveučilište, Sari, Mazandaran, Iran. ${ }^{2}$ Autor je profesor Odjela za znanost i tehnologiju drva i papira, Islamsko sveučilište, Chaloos, Mazandaran, Iran. ${ }^{3}$ Autor je profesor Istraživačkog centra za poljoprivredu i prirodne resurse u Mazandaranu, Sari, Iran.
} 
utjecaj izvora sjemena na navedena svojstva značajan, tako da su sva istraživana fizikalna svojstva imala najveće vrijednosti za drvo običnog bora od sjemena iz Španjolske. Nije bilo značajne razlike između gustoće i promjena dimenzija (volumno utezanje i volumno bubrenje) za drvo čije je sjeme podrijetlom iz Armenije $i$ Srbije (bivša Jugoslavija). Odnosi među različitim svojstvima drva analizirani su primjenom linearne regresije. Utvrđena je slaba i negativna ovisnost gustoće apsolutno suhog drva i standardne gustoće o visini i promjeru drveća. Korelacija između gustoće apsolutno suhog drva i promjena dimenzija drva pokazala je da postoji pozitivna ovisnost za sva tri sjemena različitog podrijetla, s tim da je koeficijent korelacije veći za sjeme iz Armenije nego za sjeme s druge dvije lokacije.

Ključne riječi: podrijetlo, sjeme običnog bora, gustoća apsolutno suhog drva, standardna gustoća, volumno utezanje, volumno bubrenje

\section{INTRODUCTION}

\section{UVOD}

About 60 years ago, afforestation was carried out of various exotic coniferous species in Iran, particularly in the Iranian three major provinces of Giulan, Mazandaran and Golestan, in order to produce quality wood. One of these species is Scots pine, which has been cultivated in the Saravan (in Giulan province), and Garagpas, Ajabit, Azarak and Atrachal in Chaloos, Sangdeh in Sari (Mazandaran Province) and Ramian and Golidagh (Golestan province). The advent of this species was instigated by seeds from different countries such as Yugoslavia (Serbia), Armenia, Spain, Turkey and France.

Scots Pine (Pinus sylvestris) is a fast growing coniferous tree with a straight trunk reaching to a height of 50 meters and 1.2 meters in diameter. This species has spread in a wide area of Europe from western Scotland to eastern Siberia, and from Scandinavian countries to the south of Spain. In Scotland, these trees provide valuable and unique forests replacing other native coniferous species (Sindair, 1999), they cover an area of about 1.28 million hectares of forests in Scotland and 700,000 to 650,000 hectares of plantation forests in Spain (Alia et al., 2000; Montrero et al., 2001; Munoz et al., 2008). Nowadays, Scots pine has spread in the mountainous regions of North, Central and West Europe (at the altitude from 500 to 2400 meters), and in southern Europe and in Eurasia and other continents in the south-eastern and north-eastern Canada and the United States through planting and cultivating (Steven and Carlisle, 1959). Scots pine is one of the most important commercial and woody species in Europe with a good quality and is used in various industries such as veneer, paper, furniture and parquet (Zare, 2001; Peltola et al., 2009).

Wood density is an important feature of wood quality affecting the strength properties of wood, swelling and pulp yield (West, 2006). In softwoods, the growth rate increase with changes in the early wood causes a reduction in density and mechanical properties of the wood (Panshin and de Zeeuw, 1980). In softwoods (Bouffier et al., 2003; Hashemi and Kord, 2011; Kiaei, 2011; Kiaei et al., 2012), particularly Scots pine (Mutz et al., 2004; Repola, 2006; Munoz et al.; 2008), wood density along radial direction increases from the pith to the bark and decreases in the longitudinal axis of the tree from the bottom to the top. Pinus sylvestris grown in the central part of Lithuania has lower density, more lignin and extractives, and equal amounts of cellulose and ash in comparison to Pinus contorta (Sable et al., 2012).

In literature, few researches have been conducted on the effect of seed sources on different properties of softwoods worldwide. For example, Matziris et al. (1979) in a research entitled "Seed Source Effect on Pinus Radiante Density in Two Sites of Greece” reported that the effect of seed sources (Australian, New Zealand and Spanish seeds) on the Pinus radiate density was not significant, while the site-independent effects on the density and interactions between seed source and site were significant.

In Iran, researches were conducted on longitudinal growth, diameter and survival of Scots pine of different seed sources, as for example the researches by Kiasri et al. (2011) and Rezaei Taleshi (2012), while there has been no particular study about the seed source impact on wood properties of Scots pine in Iran. This study sought to examine the seed source effect on physical properties of Scots pine species (seed source: Spain, Armenia and Serbia) and was conducted to determine the relationship among various properties of the wood.

\section{MATERIALS AND METHODS 2. MATERIJALI I METODE}

In this study, nine clear non-native Scots pine trees (without zone lines, reaction wood, decay, and insect damage, or fungal infection) of three different seed sources (Spain, Serbia and Armenia) were chosen from Venmek forestry projects in Neka (three trees from each seed source) and a disk of $5 \mathrm{~cm}$ thickness was cut from each tree at breast height. The related features (height, diameter and tree age) of each tree of various seed sources are shown in Table 1. All of the trees have juvenile wood due to low age. Due to the trees small diameter, the samples were spread across the disks based on the standard ISO-3131 to determine and calculate the physical properties (oven-dry density, basic density, volumetric shrinkage and volumetric swelling). A total of 150 samples were selected, 50 for each different seed source.

Vanamak-Neka is a region located in Neka in the eastern part of Mazandaran province. Mazandaran province is located in Northern Iran. The average annual temperature is about $15.7^{\circ} \mathrm{C}$ and the total annual rainfall reaches $1186 \mathrm{~mm}$, meaning that this region has a cold-humid climate with cool winters. The altitude is 760 meters from the sea level. The soil depth in this 
Table 1 Tree characteristics of three different seed sources for Scote pine (Pinus sylvestris L.)

Tablica 1. Obilježja stabala običnog bora (Pinus sylvestris L.) od tri sjemena različitog podrijetla

\begin{tabular}{|c|c|c|c|}
\hline $\begin{array}{c}\text { Seed source } \\
\text { Podrijetlo sjemena }\end{array}$ & $\begin{array}{c}\text { Diameter, cm } \\
\text { Promjer, } \mathrm{cm}\end{array}$ & $\begin{array}{c}\text { Height, } \mathbf{m} \\
\text { Visina, } m\end{array}$ & $\begin{array}{c}\text { Age, years } \\
\text { Starost, god. }\end{array}$ \\
\hline $\begin{array}{c}\text { Serbia } \\
\text { Srbija - ex Jugoslavija }\end{array}$ & 10.47 & 7.47 & 16 \\
\hline $\begin{array}{c}\text { Armenia } \\
\text { Armenija }\end{array}$ & 10.06 & 7.20 & 16 \\
\hline $\begin{array}{c}\text { Spain } \\
\text { Spanjolska }\end{array}$ & 8.03 & 4.32 & 16 \\
\hline
\end{tabular}

region ranges from deep to very deep and the clay soil content increases with the increase of the depth (Kiasari et al., 2011).

After preparing the samples, the relevant experiments, including weighing and measuring the dimensions, were conducted. In the first stage, the sample volumes and weights (after cutting the sample) were measured. Then, the samples were placed in water for 48 hours so as to be completely immersed in water or become saturated with water. After that, the sample weight and saturated volume were determined using a digital scale and caliper. The third stage included putting the samples in an oven for 48 hours at $103 \pm 2{ }^{\circ} \mathrm{C}$ to completely dry the samples and afterward the sample volume and weight were measured in a dry state. Finally, the ovendry density, basic density, volumetric shrinkage and volumetric swelling were calculated by using the following formulas:

$$
D_{0}=M_{0} / V_{0} \quad\left(\mathrm{~kg} / \mathrm{m}^{3}\right)
$$

Where $M_{0}$, and $V_{0}$ are the oven-dry weight $(\mathrm{kg})$ of the specimen and volume $\left(\mathrm{m}^{3}\right)$ of specimen, respectively.

$$
D_{\mathrm{b}}=M_{0} / V_{\mathrm{s}} \quad\left(\mathrm{kg} / \mathrm{m}^{3}\right)
$$

Where $D_{\mathrm{b}}$ is the basic density, $M_{0}$ is the oven dry weight and $V_{\mathrm{s}}$ is the saturated volume of specimen.

$$
\begin{array}{ll}
\beta_{\mathrm{v}}=\left(V_{\mathrm{s}}-V_{0}\right) / V_{\mathrm{s}} & (\%) \\
\alpha_{\mathrm{v}}=\left(V_{\mathrm{s}}-V_{0}\right) / V_{0} & (\%)
\end{array}
$$

Where $\beta_{\mathrm{v}}, \alpha_{\mathrm{v}}, V_{\mathrm{s}}, V_{0}$ are the volumetric shrinkage, volumetric swelling, saturated volume and oven-dry volume, respectively.

\subsection{Statistical analysis \\ 2.1. Statistička analiza}

To determine the seed source effect on the physical properties (oven-dry density, basic density, volumetric shrinkage and volumetric swelling), statistical analysis was conducted using the SPSS programming method in conjunction with the analysis of variance (ANOVA) techniques. Duncan's multiple range test (DMRT) was used to test the statistical significance at $\alpha=0.05$ and $\alpha=0.01$ levels. The linear regression was used to analyze the relationship among various properties of the wood.

\section{RESULTS}

3. REZULTATI

\subsection{Oven-dry density}

3.1. Gustoća u apsolutno suhom stanju

The mean oven-dry density of Scots pine samples of various seed sources from Spain, Armenia and

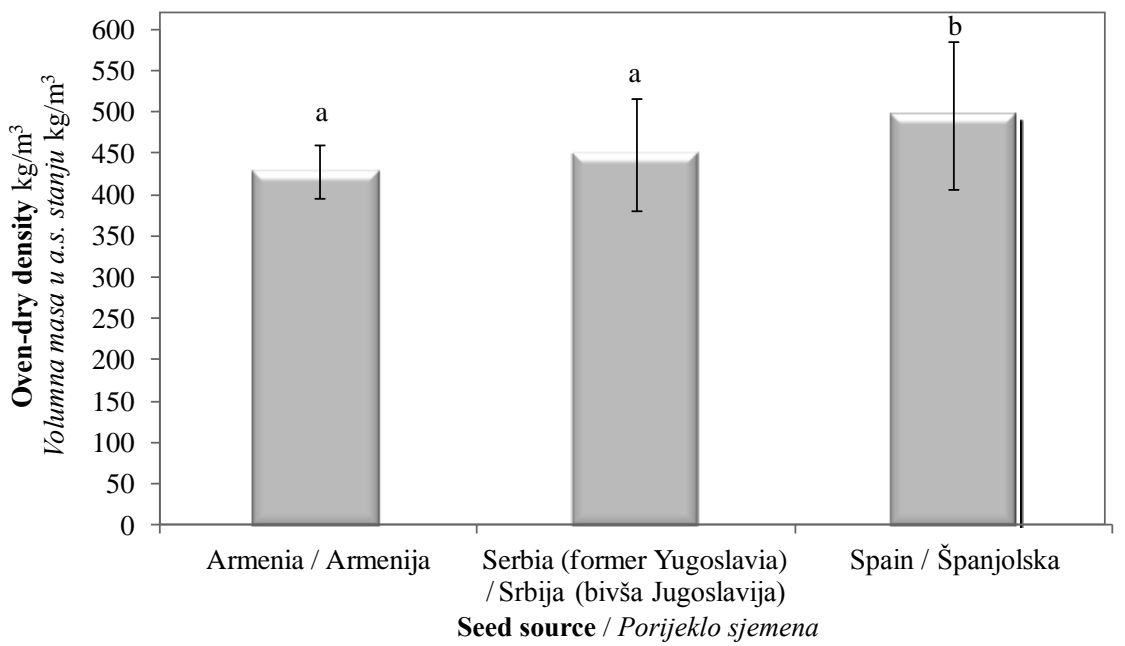

Figure 1 The average basic oven-dry density for different seed sources of Scots pine (Results with different letters (a and b) are significantly different by Duncan's test)

Slika 1. Prosječne vrijednosti gustoće drva u apsolutno suhom stanju običnog bora od sjemena različitog podrijetla (rezultati označeni različitim slovima, a i b, značajno se razlikuju prema Duncanovu testu) 


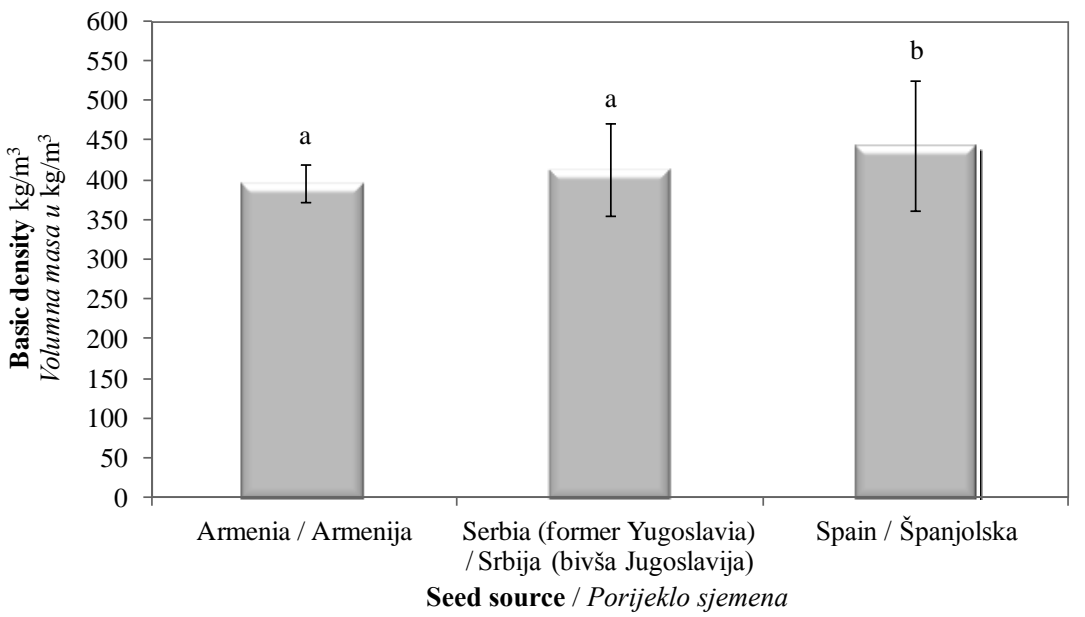

Figure 2 The average basic density for different seed sources of Scots pine (Results with different letters (a and b) are significantly different by Duncan's test).

Slika 2. Prosječne vrijednosti standardne gustoće drva običnog bora od sjemena različitog podrijetla (rezultati označeni različitim slovima, a i b, značajno se razlikuju prema Duncanovu testu)

Serbia are shown in Figure 1. The variance analysis results showed that the seed source effect on the Scots pine oven-dry density was significant $(F=6.108$, $p \leq 0.01$ ); so the wood oven-dry density of the Spanish seed source $(496 \mathrm{~kg} / \mathrm{m} 3)$ was $10.4 \%$ and $15.8 \%$ higher than the Serbian and Armenian seeds, respectively. The Duncan table classified the average oven-dry density of the Armenian and Serbian seeds in one group, and the average oven-dry density obtained from the Spanishseeds in another group.

\subsection{The basic density}

\subsection{Standardna gustoća}

The mean basic density of Scots pine samples of various seed sources from Spain, Armenia and Serbia are presented in Figure 2. The variance analysis results showed that the seed source effect on the Scots pine basic density was significant $(F=3.594, p \leq 0.05)$; so the wood basic density of the Spanish seed source $\left(443 \mathrm{~kg} / \mathrm{m}^{3}\right)$ was $7.2 \%$ and $11.8 \%$ higher than the average of the Serbian and Armenian samples, respectively. The Duncan table classified the average basic density of the Armenian and Serbian seeds in one group, and the average basic density obtained from the Spanish seeds in another group.

The linear regression between the oven-dry density and basic density with the tree longitudinal and diametrical growth is shown in Figure 3. The results showed that there is an insignificant (weak and negative correction) relationship between wood density and the tree diameter and height. The strongest correlation was observed between oven-dry density and longitudinal growth of trees $(-0.243)$ and the weakest correlation was observed between the basic density and tree diameter (-0.138).

\subsection{Volumetric shrinkage}

\subsection{Volumno utezanje}

The average volumetric shrinkage for Scots pine wood samples of various seed sources from Spain, Armenia and Serbia are given in Figure 4. The variance analysis results showed that the seed source effect on the Scots pine volumetric shrinkage was significant $(F=$
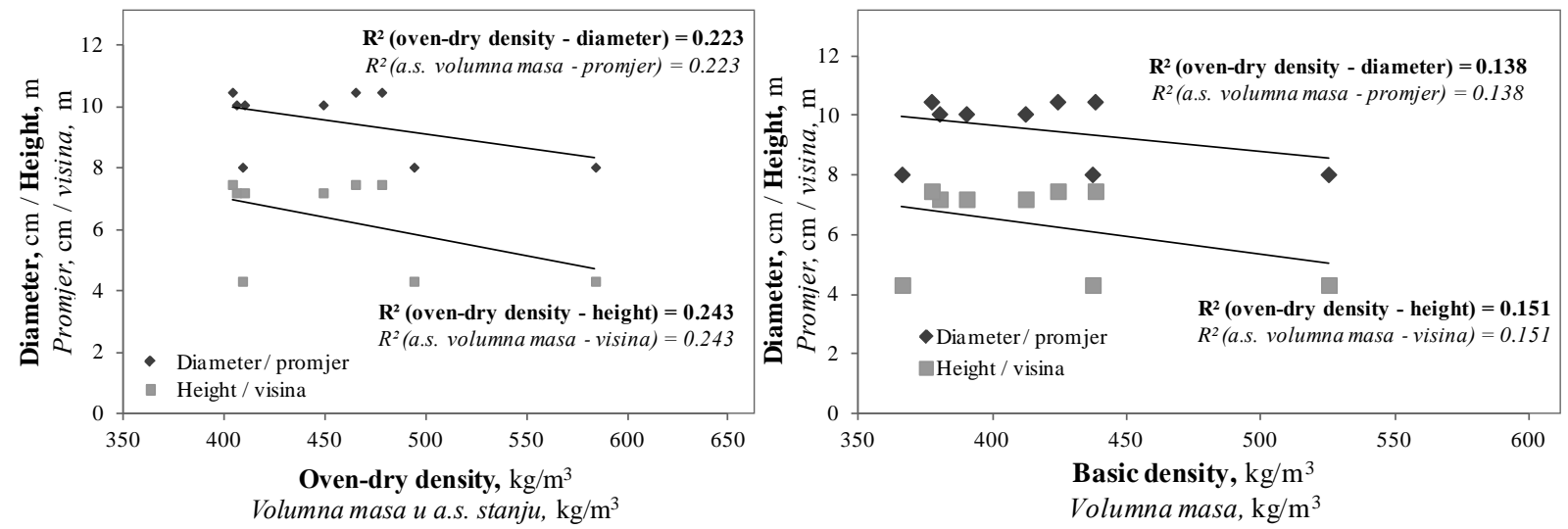

Figure 3 The relationship between oven-dry density (left) and basic density (right) with tree longitudinal and diametrical growth in combined seed sources; there are no significant differences

Slika 3. Odnos gustoće apsolutno suhog drva (lijevo) i standardne gustoće (desno) te visine i promjera stabala za sjemena različitog podrijetla; ne postoji značajna ovisnost 
.... Farsi, Kiaei, Miar, Kiasari: Effect of Seed Source on Physical Properties of Scots Pine...

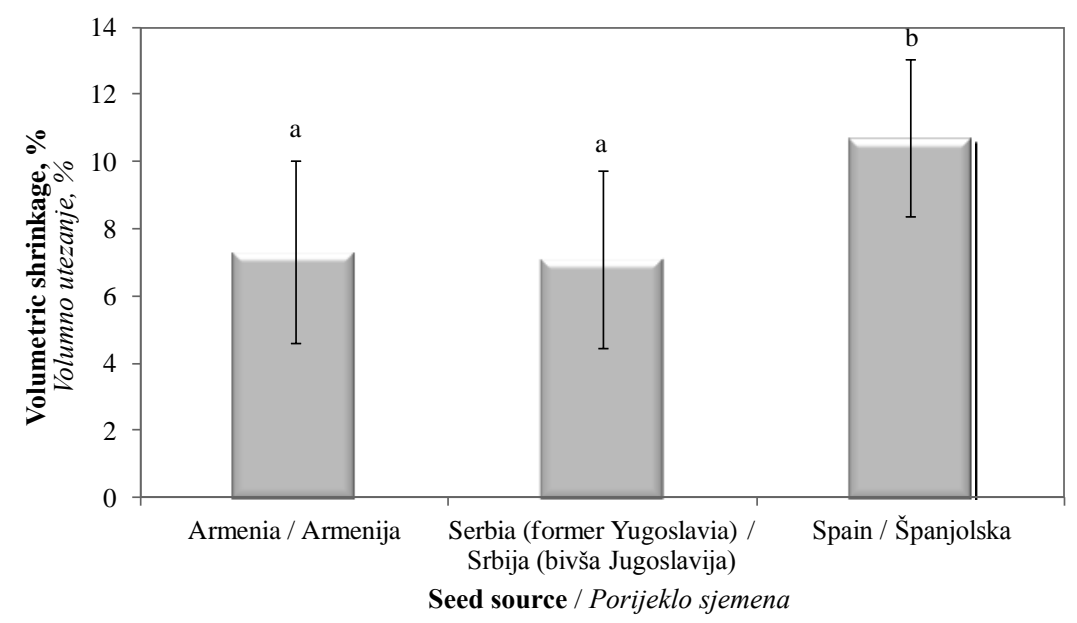

Figure 4 The average volumetric shrinkage for different seed sources of Scots pine (Results with different letters (a and b) are significantly different by Duncan's test).

Slika 4. Prosječne vrijednosti volumnog utezanja drva običnog bora od sjemena različitog podrijetla (rezultati označeni različitim slovima, a i b, značajno se razlikuju prema Duncanovu testu)

17.449, $p \leq 0.01)$; so the wood volumetric shrinkage of wood samples of the Spanish seed source (10.70\%) was $7.2 \%$ and $11.8 \%$ higher than the average of wood samples of the Serbian and Armenian seed sources, respectively. The Duncan table classified the average volumetric shrinkage of the Armenian and Serbian samples in one group, and the average volumetric shrinkage gained from the Spanish wood samples in another group.

\subsection{Volumetric swelling}

\subsection{Volumno bubrenje}

The average volumetric swelling for Scots pine wood samples of various seed sources from Spain, Armenia and Serbia are given in Figure 5. The variance analysis results showed that the seed source effect on the Scots pine volumetric swelling was significant $(F=$ 17.589, $p \leq 0.01$ ); so the wood volumetric swelling of samples of the Spanish seed source (12.06 \%) was 55.8 $\%$ and $50.9 \%$ higher than the average of the Serbian and Armenian seeds, respectively. The Duncan table classified the average volumetric swelling of the Armenian and Serbian seed samples in one group, and the average volumetric swelling acquired from the Spanish seed samples in another group.

\subsection{Relationship between wood density and swelling/shrinkage}

\subsection{Odnos između gustoće drva i bubrenja/utezanja}

The relationship between oven-dry density and dimension variations (swelling and shrinkage) from the Armenian (Figure 6a), Serbian (Figure 6b) and Spanish seed sources (Figure 6c) showed that there is a positive and significant relationship between wood density and swelling/shrinkage, so that the correlation coefficient of Scots pine grown from the Armenian seed source was higher than that from the Serbian and Spanish seed sources. The correlation coefficients between wood density and swelling are slightly higher than those between wood density and shrinkage for the Armenian and Serbian seed sources, while the opposite applies for the Spanish seed sources.

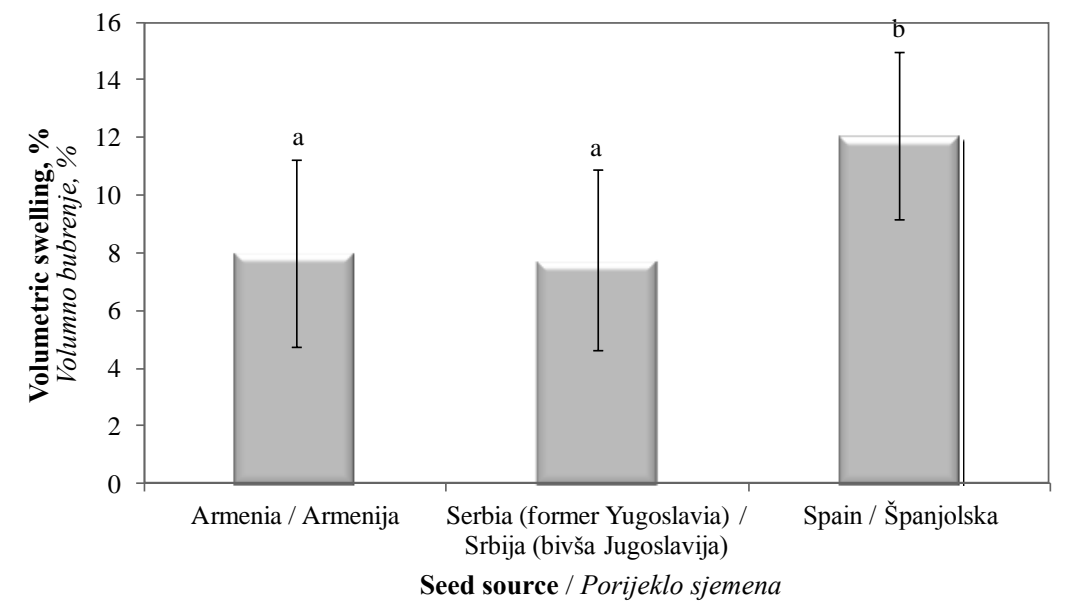

Figure 5 The average volumetric swelling for different seed sources of Scots pine (Results with different letters (a and b) are significantly different by Duncan's test).

Slika 5. Prosječne vrijednosti volumnog bubrenja drva običnog bora od sjemena različitog podrijetla (rezultati označeni različitim slovima, a i b, značajno se razlikuju prema Duncanovu testu) 


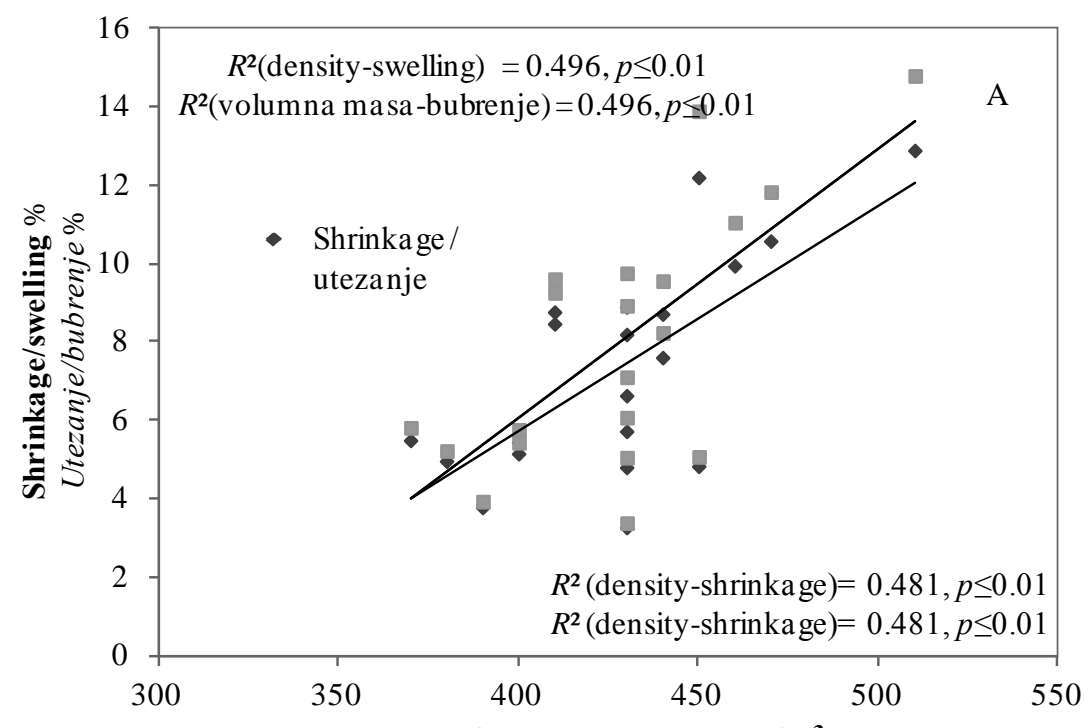

Oven-dry density, $\mathbf{k g} / \mathrm{m}^{3}$

Masa $u$ a.s. stanju, $\mathrm{kg} / \mathrm{m}^{3}$
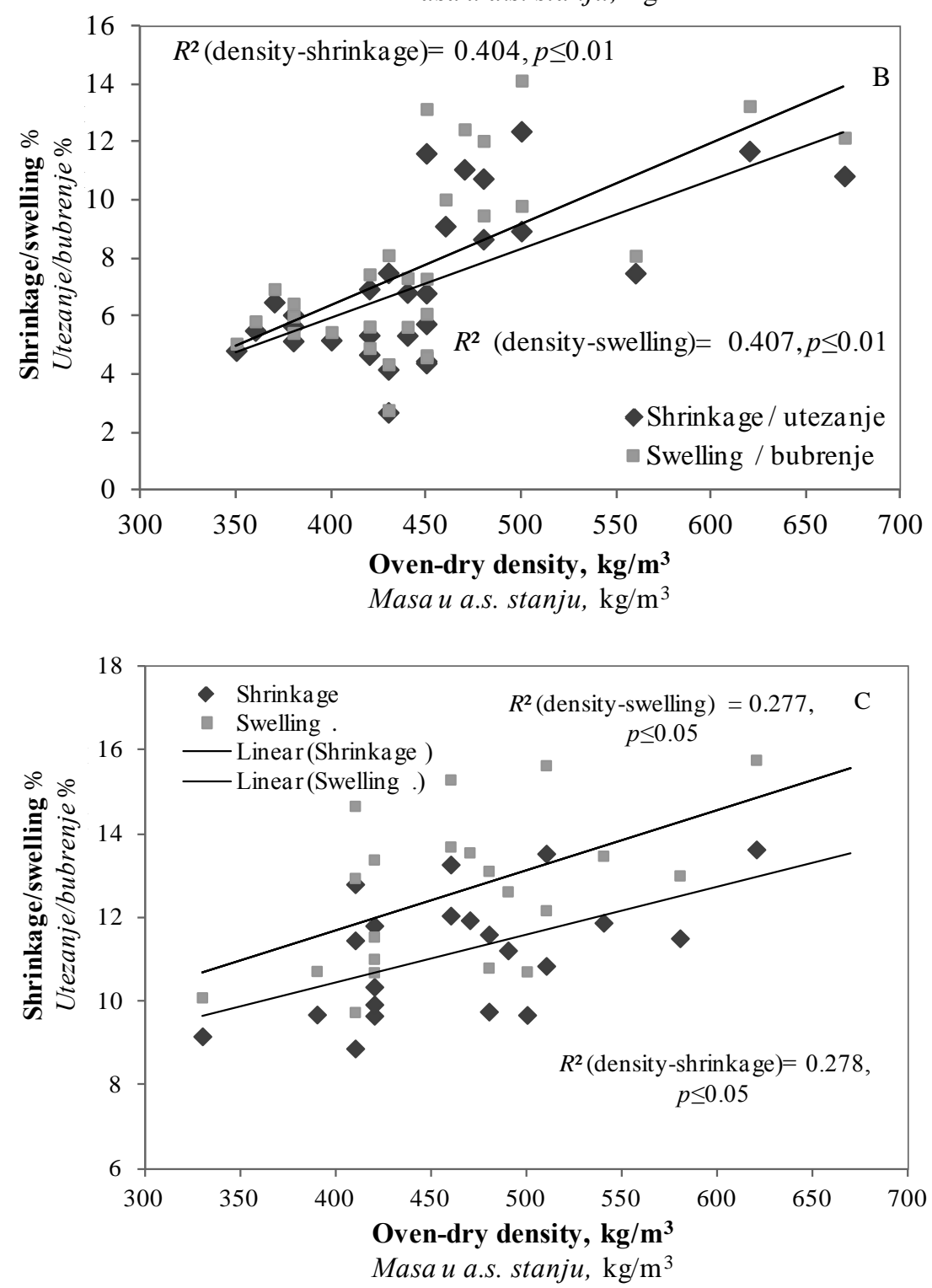

Figure 6 The relationship between density and swelling/shrinkage of wood from Armenian (A), Serbian (B) and Spanish (C) seed sources

Slika 6. Odnos između gustoće i bubrenja/utezanja drva od sjemena podrijetlom iz Armenije (A), Srbije - bivše Jugoslavije (B) i Španjolske (C) 


\section{DISCUSSION}

\section{RASPRAVA}

Variations of wood properties of juvenile wood are much higher than those of mature wood. The juvenile wood has lower density and mechanical strength than mature wood (Zobel and van Buijtenen, 1989). All tree samples (studied seed sources) have juvenile wood due to lower age. Therefore, the transition age between juvenile and mature wood did not occur for these tree samples.

The present study showed that the impact of seed sources on the oven-dry density and the basic density of Scots pine was significant, which is inconsistent with the results of the study on Pinus radiata by Matziris (1979). The wood density of Scots pine wood grown from the Spanish seed source was higher than that from the Armenian and Serbian seed sources.

In general, the wood density is influenced by factors such as genotype, ageing of the cambium, cell walls thickness and growth rate, so that by increasing the cell wall thickness and decreasing of the early wood percentage, the wood density increases (Panshin and de Zeeuw, 1980). Therefore, it is expected that the cell wall thickness of Scots pine wood grown from the Spanish seed source would be higher than that of samples from the Armenian and Serbian seed sources.

Since all mechanical properties of wood are closely related to wood density and some wood strength factors are more associated with wood density, it is expected that wood strength of Scots pine grown from the Spanish seed source would be higher than wood grown from the Armenian seed source. This is an important issue in the design of wooden structures due to the fact that the interdependence between density and mechanical properties of wood has been proven for many coniferous species (Abies fabri, Abies nephrolepis, Picea asperata, Piceae koraiensis, Larix gmelini, Larix olgensis, Pinus massoniana, Pinus yunnanensis, Pinus eldarica) (Zhang, 1997; Kiaei, 2011). Various mechanical properties of wood are also dependent on tracheid dimensions such as length and diameter (Panshin and de Zeeuw, 1980; Quilho et al., 2006).

The results show that there is a weak and insignificant relationship between oven-dry density / basic density and the tree height / diameter growth of Scots pine trees grown from combined seed sources (Armenian, Serbian and Spanish). Similar trend has been reported by Matziris (1979) and Burdon and Harris (1973). They state that the Pinus radiata density has a weak negative correlation with the tree breast height diameter and that it is not related to the tree height.

The average oven-dry density of Scots pine grown from the Armenian, Serbian and Spanish seed sources was $457 \mathrm{~kg} / \mathrm{m}^{3}$, which is similar to the average oven-dry density of Scots pine grown in Lithuania (Sable et al., 2012). Also, this characteristic of Scots pine is lower than other pine species such as (Alden, 1997): P. banksiana $\left(460 \mathrm{~kg} / \mathrm{m}^{3}\right)$, P. echinata $\left(540 \mathrm{~kg} / \mathrm{m}^{3}\right), P$. elliotti $\left(660 \mathrm{~kg} / \mathrm{m}^{3}\right)$, P. palustris $\left(620 \mathrm{~kg} / \mathrm{m}^{3}\right)$, P. pungens $\left(550 \mathrm{~kg} / \mathrm{m}^{3}\right), P$. resinosa $\left(510 \mathrm{~kg} / \mathrm{m}^{3}\right), P$. rigida $\left(520 \mathrm{~kg} / \mathrm{m}^{3}\right)$, P.teada $\left(540 \mathrm{~kg} / \mathrm{m}^{3}\right)$ and is higher than other pine species such as: $P$. contorta $\left(430 \mathrm{~kg} / \mathrm{m}^{3}\right), P$. jeffreyi $\left(420 \mathrm{~kg} / \mathrm{m}^{3}\right)$, P. lambertiana $\left(380 \mathrm{~kg} / \mathrm{m}^{3}\right), P$. monticola $\left(420 \mathrm{~kg} / \mathrm{m}^{3}\right)$, P. strobes $\left(370 \mathrm{~kg} / \mathrm{m}^{3}\right)$. Since wood density of Scots pine grown from the Armenian seed source is lower than the density of wood grown from other seeds, it may affect the wood pulp production. In a digester, an equal volume of Scots pine wood grown from the Spanish seed source (with higher density) produces more wood pulp. As most properties of the wood pulp are related to the density (Panshin and de Zeeuw, 1980; Zobel and van Buijtenen, 1989; Sable et al., 2002), there are positive relationships between wood density and bulk, freeness, bending stiffness, light scattering, opacity and tear index, while there are negative correlations with tensile index, burst and stretch (Wimmer et al., 2002).

The basic density of Scots pine grown from the Spanish seed source is about $433 \mathrm{~kg} / \mathrm{m} 3$, which is almost similar to the basic density of the wood grown in Spain (430 kg/m3, Munoz et al, 2008) and in southern Finland (435 kg/m3, Repola, 2006). Wood with the basic density of $400-600 \mathrm{~kg} / \mathrm{m} 3$ is suitable for pulp production (Downes et al., 1997), which is the case of Scots pine grown from the Armenian, Serbian and Spanish seed sources. For more precise results, the tracheid dimensions, morphological coefficients and their chemical compounds must be investigated. A wood species can be considered suitable for pulp production if it has long fibers, high degrees of cellulose, and a low content of lignin, extractives and ash (Zobel and van Buijtenen, 1989; Sable et al., 2012). There are positive relationships between fiber length and burst strength (Casey, 1952; Miyake, 1968; El-Hosseiny and Anderson, 1999; Ona et al., 2001), tensile strength (Casey, 1952; Miyake, 1968), tear strength (Casey, 1952; Haygreen and Bowyer, 1996) and folding endurance (Dinwoodie, 1965; Ona et al., 2001).

Shrinkage and swelling are related to changes in wood dimensions affected by changes in wood moisture, which occurs between the dry phase and moisture saturation point of wood (Pang, 2002). This phenomenon is affected by factors such as the heartwood and sapwood proportion, microfibril angle in the secondary layer, etc. (Bektas and Guler, 2001). However, density is the most important parameter that affects wood volumetric shrinkage and swelling (Guler et al., 2007). Volumetric swelling and shrinkage rate of the Scots pine grown from the Spanish seed source was higher than that of Scots pine grown from the Serbian and Armenian seed sources, which can be attributed to the above factors. The results of the analysis of oven-dry density and volumetric swelling and shrinkage showed a significant positive correlation between these properties in Scots pine, which is consistent with the results of Munoz et al. (2008). They estimated the Pearson correlation coefficient for the relationship between the basic density and volumetric shrinkage of Spanish Scots pine to be $R=0.624$. 


\section{CONCLUSION 5. ZAKLJUČAK}

This study evaluated the seed source effect on the density of non-native Scots pine wood and dimensional changes depending on the Spanish, Armenian and Serbian seed sources. The following results were obtained:

1. The seed source effect on the oven-dry density, basic density, volumetric swelling and shrinkage was significant so that the effect of these properties of the Spanish seed source is higher than that of the Armenian and Serbian seed sources. There is a positive and significant relationship between oven-dry density and dimensional changes of wood, but the values of correlation coefficient are stronger with the Armenian seed source than with the Spanish and Serbian seeds.

2. There is a weak and negative relationship between longitudinal and diametrical growth of trees grown from the combined seed sources (Spanish, Armenian and Serbian seeds) and the basic and oven-dry density.

3. The basic density of wood grown from the Spanish, Armenian and Serbian seeds is suitable for paper production. According to a short-term production of wood, Scots pine species with seeds originating from Armenia and Serbia are more suitable than those from Spain, because these species, in addition to being suitable for paper production, reach the desired diameter and length within a short time. As the Iranian forest resources are relatively poor, this fact can be decisive for the cultivation of Scots pine with seeds originating from Armenia and Serbia. Diameter and longitudinal growth of Scots pines from Armenia and Serbia are more than $10 \mathrm{~cm}$ and $7 \mathrm{~cm}$, respectively, which is a higher growth than that of Scots pines from Spain.

4. Scots pine wood grown from the Spanish seed is more suitable for mechanical applications than the other two seed sources due to its high density.

\section{REFERENCE}

\section{LITERATURA}

1. Alden, H.A., 1997: Softwoods of North America. Gen. Tech. FPL-GTR-102. U.S. Department of Agriculture, Forest Service, Forest Product Laboratory, Madison, WI, USA.

2. Alía, R.; Moro-Serrano, J.; Notivol, E., 2001: Genetic variability of scots Pine (Pinus sylvestris) provenances in Spain: Growth traits and survival. Silva Fennica 35 (1): 27-38.

3. Bektas, I.; Guler, C., 2001: Determination of some physical properties of beech wood (Fagus orientalis Lipsky) from Andirin region. Turkish Journal of Agriculture and Forestry 25:209-215.

4. Bouffier, L.A.; Gartner, B.L.; Domec, J.C., 2003: Wood density and hydraulic properties of Ponderosa pine from the Willamette valley VS. The Cascade mountains. Wood and Fiber Science 35 (2):217-233.

5. Burdon, R.; Harris. J., 1973: Wood density in radiate pine clones on four different sites. New Zealand Journal of Forestry Science 3 (3): 286-303.
6. Casey, J.P., 1952: Properties of paper and converting. In: Pulp and Paper Chemistry and Chemical Technology. Volume 2. Interscience Publisher Inc., New York, p. 835837.

7. Dinwoodie, J.M., 1965: The relationship between fibre morphology and paper properties: a review of literature. Tappi Journal 48: 440-447.

8. Downes, G. M.; Hudson, I. L.; Raymond, C.A.; Dean, G. H.; Michell, A. J.; Schimleck, L. S.; Evans, R.; Muneri. A., 1997: Sampling Plantation Eucalypts for Wood and Fibre Properties. CSIRO Publishing, Melbourne, Australia, $132 \mathrm{pp}$.

9. El-Hosseiny, F.; Anderson, D.; 1999: Effect of fibre length and coarseness on the burst strength of paper. Tappi Journal 82: 202-203.

10. Guler, C.; Copur, Y.; Akgul, M.; Buyukasari, U., 2007: Some chemical, physical and mechanical properties of juvenile wood from black pine (Pinus nigra Arnold) plantations. Journal of Applied Science 7(5):755-758.

11. Hashemi, S.K.; Kord, B., 2011: Variation of within-stem biometrical and physical property indices of wood from Cupressus sempervirens L. Bioresource 6(2): 1843-1857.

12. Haygreen, J. G.; Bowyer, J. L., 1996: Forest Products and Wood Science: An Introduction. Third edition. Iowa University Press, Ames.

13. Kiaei, M., 2011: Anatomical, physical and mechanical properties of eldar pine (Pinus eldarica Medw.) grown in the Kelardashat region. Turkish Journal of Agriculture and Forestry 35: 31-42 http://dx.doi.org/10.3906/tar-1001-552

14. Kiaei, M.; Khademi-Eslam, H.; Hemmas, A.H.; Samariha, A., 2012: Ring Width, Physical and Mechanical Properties of Eldar Pine (Case Study on Marzanabad Site). Cellulose Chemistry and Technology 46(1-2): 125-135.

15. Kiasari, S.M.N.; Mousavi, S.A.; Amini, S.; Borhani, A.; Jafari, B.; Raeysian, H., 2011: An investigation of the adaptation of the most important conifers of the world at moderate altitude of Neka Forests (Vanamak). Journal of Sciences and Techniques in Natural Resources 6(4):2537.

16. Matziris, D.I., 1979: Variation of wood density in radiata pine grown from four seed sources at two sites in Greece. Silvae Genetica 28: 104-106.

17. Miyake, M., 1968: Wood characteristics and kraft pulp properties of hardwood grown in Hokkaido. Japan Tappi 22: 600-610.

18. Montero, G.; Cañellas, I.; Ortega, C.; Del-Río, M., 2001: Results from a thinning experiment in a Scots pine (Pinus sylvestris L.) natural regeneration stand in the Sistema Ibérico Mountain Range (Spain). Forest Ecology and Management 145: 151-161.

19. Munoz, G.R.; Canas M.A.S.; Soalleiro, R.R., 2008: Physical properties of wood in thinned Scots pine (Pinus sylverstris L.) from plantations in northern Spain. Annual of Forest Science 65: 507p1-p8. http://dx.doi.org/ 10.1051/forest: 2008026

20. Mutz, R.; Guilley, E.; Sauter, U.H.; Nepveu, G., 2004: Modelling juvenile-mature wood transition in Scots pine(Pinus sylvestris L.) using nonlinear mixed-effects models. Annual of Forest Science 61: 831-841 http://dx.doi.org/10.1051/forest:2004084

21. Ona, T.; Sonoda, T.; Ito, K.; Shibata, M.; Tamai, Y.; Kojima, Y.; Ohshima, J.; Yokota, S.; Yoshizawa, N., 2001: Investigation of relationship between cell and pulp properties in Eucalyptus by examination of within-tree property variations. Wood Science and Technology 35: 363375. 
22. Panshin, A.; de Zeeuw, C., 1980: Textbook of Wood Technology. 4th ed. McGraw-Hill, New York.

23. Pang, S., 2002: Predicting anisotropic shrinkage of softwood part 1: theories. Wood Science and Technology 36 (1): 75-91

24. Peltola, H.; Gort, J.; Pulkkinen, P.; Gerendiain, A.Z.; Karppinen, J.; Ikonen, V.P., 2009: Differences in growth and wood density traits in Scots Pine (Pinus sylvestris L.) genetic entries grown at different spacing and sites. Silva Fennica 43(3): 339-354 http://www.metla.fi/silvafennica/full/sf43/sf433339.pdf

25. Quilho, T.; Miranda, I.; Pereira, H., 2006: Within-tree variation in wood fibre biometry and basic density of the urograndis eucalyptus hybrid (Eucalyptus grandis $\times \mathrm{E}$. urophylla. 2006. IAWA Journal 27(3): 243-254.

26. Repola, J.; 2006: Models for vertical wood density of Scots Pine, norway spruce and birch stems, and their application to determine average wood density. Silva Fennica 4(4): 673-685

http://www.metla.fi/silvafennica/full/sf40/sf404673.pdf

27. Rezaei Taleshi, S.A., 2012: An adaptation study on four provenances of Scotch pine (Pinus sylvestris Linn) (Case study: Ladjim forest, Mazindaran). Iranian Journal of Forest 4 (1): 65-75.

28. Sable, I.; Grinfelds, U; Jansons, A.; Vikele, L.; Irbe, I.; Verovkins, A.; Treimanis, A.; 2012: Comparison of the properties of wood and pulp fibers from lodgepole pine (Pinus contorta) and Scots pine (Pinus sylverstris). Bioresource 7 (2): 1771-1783.

29. Sindair, W.; Morman, J.; Ennos, R., 1999: Multiple Origins for Scots pine in Scotland: evidence from mitochondrial DNA variation, Heredity 80: 233-240.
30. Steven, H.M.; Carlisle, A., 1959: The native pinewoods of Scotland. Oliver and Boyd Publications. Edinburgh, 368 pp.

31. West, P.W., 2006: Growing plantation forests. Springer Verlag, Berlin.

32. Wimmer, R.; Downes, G.M.; Evans, R.; Rasmussen, G.; French, J., 2002: Direct Effects of Wood Characteristics on Pulp and Handsheet Properties of Eucalyptus globules. Holzforschung 56: 244-252.

33. Zare, H., 2001: Introduced and native conifers in Iran. Ministry of Jihad-e-Agriculture, Agriculture Research, Education and Extension Organization, No: 271, Tehran, Iran.

34. Zhang, S.Y., 1997: Wood specific gravity-mechanical property relationship at species level. Wood Science and Technology 31: 181-191.

35. Zobel, B. J.; Van Buijtenen, J.P., 1989: Wood variation: Its causes and control. Springer- Verlag, Berlin, Heidelberg. 363 pp.

\section{Corresponding address:}

Professor MOHAMMAD FARSI and Professor MAJID KIAEI

Department of Wood and Paper Science and Technology, Sari Branch, Islamic Azad University, Sari, Mazandaran, IRAN

e-mail: mjd_kia59@yahoo.com 